\title{
ACCESS TO INTEREST-RELATED EDUCATION IN LATVIA FOR CHILDREN AND YOUNG PEOPLE: PARENTS' PERSPECTIVE
}

\author{
Dita Nīmante \\ University of Latvia, Latvia \\ Nellija Repina \\ University of Latvia, Latvia
}

\begin{abstract}
According to the Education Law of Latvia, every child in Latvia has the right to access education including interest-related education. There are several interest-related education programmes available for children and young people up to age 25 . The research seeks to discover the parent's perspective on child and youth access to interest education. This paper uses data from an on-line questionnaire developed and disseminated to parents through social media. A sample of 124 parents with experience in interest education was used. The small-scale research findings suggest the four most popular reasons why children are not attending the interest-related education programmes are: lack of information, no interestrelated classes provided or conducted, children are too busy so overload can occur, and there is no support stuff provided during the classes.

Although the majority of parents have had a positive experience concerning their children's accessibility to interest-related education, some parents have been refused access to an interest education due to children/youth's behaviour, a teacher's refusal to work with the child, social inclusion problems in the classroom, and a teacher's negative attitude. Research reveals that refusal to access is experienced more often by parents whose children have a disability. Several other issues which emerged from the research are also discussed - what are the barriers to accessibility to interest-related education and how to overcome them.
\end{abstract}

Keywords: parent's opinion, interest-related education in Latvia, access.

\section{Introduction}

The access to education is one of the main objectives of Latvia's education policy to promote equality for all the children involved. The 
Law of Education of Latvia states that, every child in Latvia has the right to access education (Education Law, 1998), including interest-related education or so-called hobby education. The interest-related education system in Latvia supports activities for the development of every personality as individual to promote their talents. It is a long-term, curriculum-based supervised education outside a formal educational setting. According to the current information provided by the National Centre for education of the Republic of Latvia (National Centre for Education, n.n.) interest-related education provides a variety of activities outside a formal education, which can also include extra-curricular activities and events. One of the tasks is to promote useful and meaningful leisure time for children and young people, considering their needs and necessities. It is a fact that an interest-related education is providing a real impact on the development of values in children and young people (Pavlovs, 2018). There are several interest-related education programmes which are implemented in Latvia in such areas as: cultural education, sports education, technical creativity, environmental education and youth work.

Usually the local municipalities in Latvia are encouraged to provide the interest-related programmes, as the Education Law (1998) stipulates that every municipality has a duty to provide children living in its administrative territory with the opportunity to implement interest-related education. According to Paragraph 1 of Article 47 of the Education Law of Latvia (1998), interest-related education is voluntary and it does not require a particular level of education to enroll in the interest-related education programmes. Interest-related education programmes are implemented usually in the afternoon hours, either at educational institutions of interest (hobby education institutions or interest education centres), or in educational institutions (comprehensive schools) which are linked with the formal education. The majority of interest-related programmes are available free of charge or for a very small co-payment. One of the most comprehensive in Latvia on interest-related education "Interestrelated Education in Latvia and the Role of Interest-related Educational Institutions" (Kalnina et al., 2012) explains that social integration and leisure and recreation programmes are also implemented in interest education institutions for children with special needs, "street" children and those who are juvenile offenders. The most recent research pointed out that children from orphanages also utilise interest education (Nīmante et al., 2018). However, the study found that the participation of these children in interest education is often limited due to the fact that every municipality offers a different quantity of interest-related programmes and the offer of interest-related education programmes may vary from one municipality to another. Access to interest education is also limited if the 
children's home is located far from the municipality centre. Those findings are in line with what has been discussed in previous studies (Kalnina et al., 2012). It means that in theory, interest-related education should be accessible for all children, but it can be limited due to geographical location.

Access is most often associated with logistics issues such as availability of transport, buildings, services and information. The main criterion for accessibility would be that the programme is easy and quick to reach, with minimal obstacles and barriers. Very often the accessibility question is raised in relation to persons with disabilities (United Nations Convention on the Rights of Persons with Disabilities, 2006, Article 9).

In the context of education, several aspects should be taken in consideration:

1. Physical accessibility - access to the building, freedom of movement, access to the classroom, gym, or facilities (Ackah-Jn \& Danso, 2019);

2. Access to information - accessibility by different users and barrier free information (European Agency for Special Needs and Inclusive Education, 2015);

3. Access to the programme - children and youth acceptance in the programme or access to the programme (Beddow, 2012);

4. Individualized and personalized support - availability of support and necessary resources (Cobb, 2015; Ramberg, 2013; Rose, Shevlin, Twomey, \& Zhao, 2017). By enhancing access to education all learners, there are less barriers for those whose individual characteristics can be viewed as challenging within the current educational system;

5. Geographical accessibility - geographical proximity to services (Kalniņa et al., 2012; Nìmante et al., 2018).

Previous research on interest-related education has mainly focused on the motives children and young people have to participate in interestrelated education (Kalnina et al., 2012; Pavlovs, 2018). However, there were further research questions recommended by Kalnina and colleagues: to find out what the reasons are for children to not attend interest-related education and what are the barriers of participation of children and young people in interest-related education. Although there is no research specifically related to interest-related education, based on research on the reasons why children and young people refuse to attend school, there is not one particular reason, but rather there are several factors which drive students away from the school: school factors (poor attendance, poor discipline policies, consequences of bad behaviour, tests), non-school factors (financial, employment, family needs, childbirth, health, illness), or the students are disengaged from school (student apathy, non-completing school work, insufficient educational support (European Agency for Special 
Needs and Inclusive Education, 2016). Children's special needs are also mentioned as one of the factors (European Agency for Special Needs and Inclusive Education, 2016).

This research seeks to discover the parent's perspective on child and youth access to interest education curriculum. There are several research questions:

- What are the reasons for children/youth to not attend interest-related education?

- Have parents experienced a refusal to their children participating in interest-related education which reduces accessibility for interest-related education?

- Is the refusal related to the child's disability?

- What are the main barriers to participation and what are possible solutions?

\section{Methodology}

The study was conducted between 10 February 2018 and 15 August 2018. A descriptive, survey research design was used. As part of the survey, there was an opportunity for parents to respond by explaining or adding information and there were two open questions provided: what are the main barriers for participation in interest-related education and how to overcome those barriers?

Questions discussed demographic information, information on children/ young people with and without disabilities, attendance of interest education programmes at both educational institutions and interest education centres, and reasons for not attending interest education classes. Parents responded to several statements that were based on complex stories about interest-related education in media and on social networks. The research also analysed respondents' experiences of access to interest education. In total, 83 questions were put to the respondents; 22 were analysed in this study.

The questionnaire was created and placed in Google sheets. Potential respondents were reached online via Facebook and through the general school e-mails. Data were collected and analysed quantitatively using mathematical statistical methods and qualitatively by summarizing respondents' statements into thematic groups. One hundred twenty-six parents responded, 120 of them were women, 6 were men, 107 were employed and 19 were unemployed. All of them have had experience with interest-related education as a parent and all of them have children between the ages of 2-25. Twelve parents stated that they have children with a disability and two parents stated that their children are in the disability assessment process. 
In Latvia, disability (invaliditate - Latvian), in accordance with Law of Disability (Invaliditātes likums [The law of disability], 2010), is a long lasting or permanent disability of a very severe, severe or moderate degree that affects a person's mental or physical abilities, ability to work, self-care and social inclusion. The limitation of a person's functioning is evaluated by the doctors of the State Commission and disability status is confirmed by an administrative act.

\section{Results}

The results of the survey show that most of the parents confirmed that their children are involved in interest-related education, however $15 \%$ of parents indicated that their children are not currently engaged in interestrelated education. The majority of parents surveyed had agreed with the statement that their children most often attend interest education classes in schools where interest education classes are offered. However, a relatively large proportion of children also attend interest education classes in interest education centres (see Figure 1).

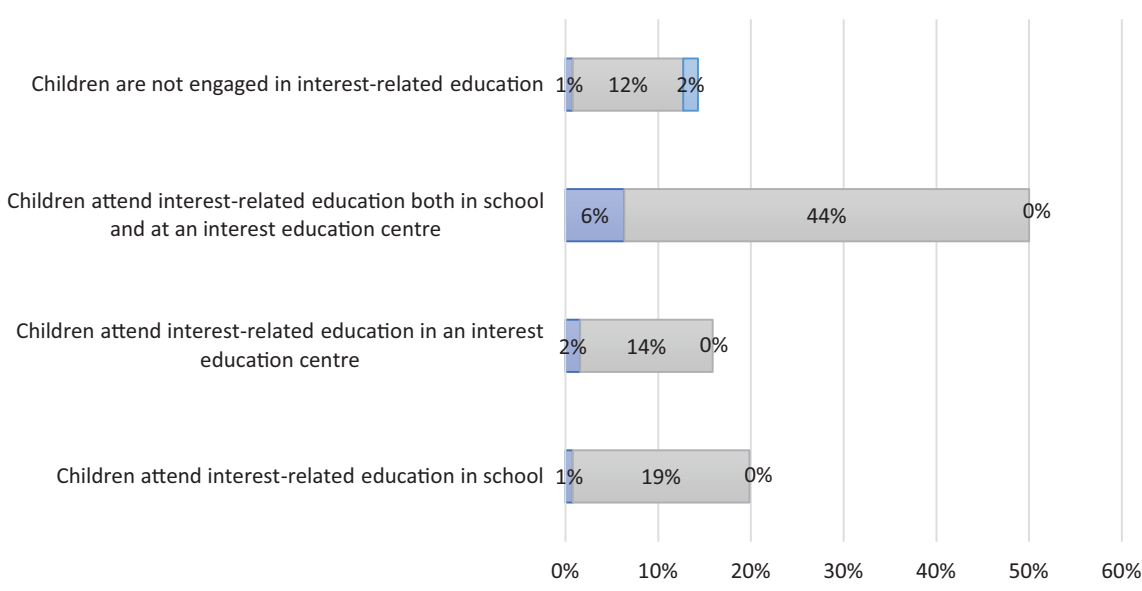

$\square$ Disability is defined $\square$ Disability is not defined $\square$ The disability determination process is currently underway

Figure 1. Attending interest education classes (\%)

When answering the question about why children do not attend interest education, the five most popular answers were: lack of information, there are no interest-related classes conducted, have no interest in the interestrelated education classes that are offered, children are too busy so overload can occur, and there is no support stuff during the classes who could assist in interest-related education (see Figure 2). 


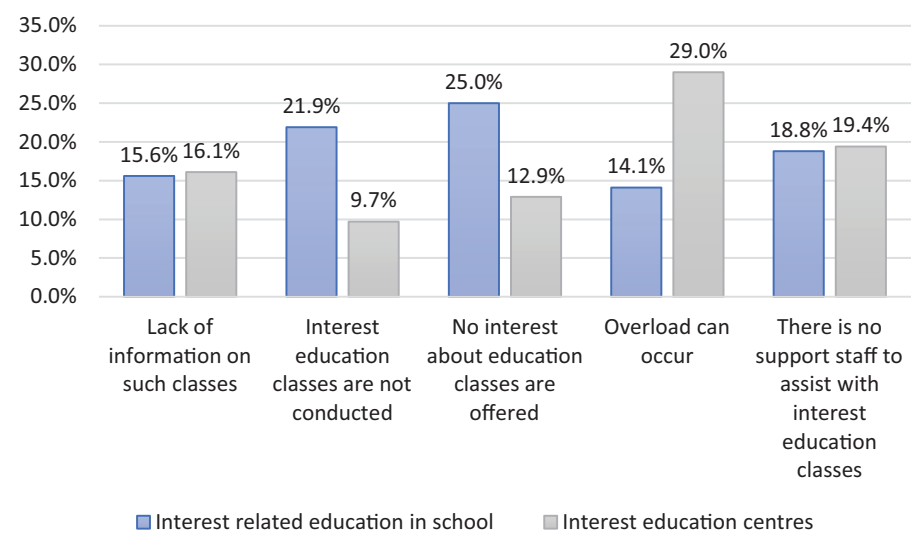

Figure 2. The reasons why children do not attend interest-related education (\%)

The researchers chose the five the most common reasons for the refusal to educate children in the interest-related education classes (i.e., due to health conditions, children/youth behaviour, a teacher's refusal to work with the child, social inclusion problems in the classroom, and a teacher's negative attitude; see Figure 3) and asked parents to provide their own experience or other parents' experience. The majority of parents supported the idea that they did not have an experience of refusal due to the five reasons mentioned above. Nevertheless, almost a fifth of respondents agreed that they have experienced some cases when children were refused access to interest-related education due to health conditions, children/ youth behaviour, a teacher's refusal to work with the child, social inclusion problems in the classroom, and a teacher's negative attitude.

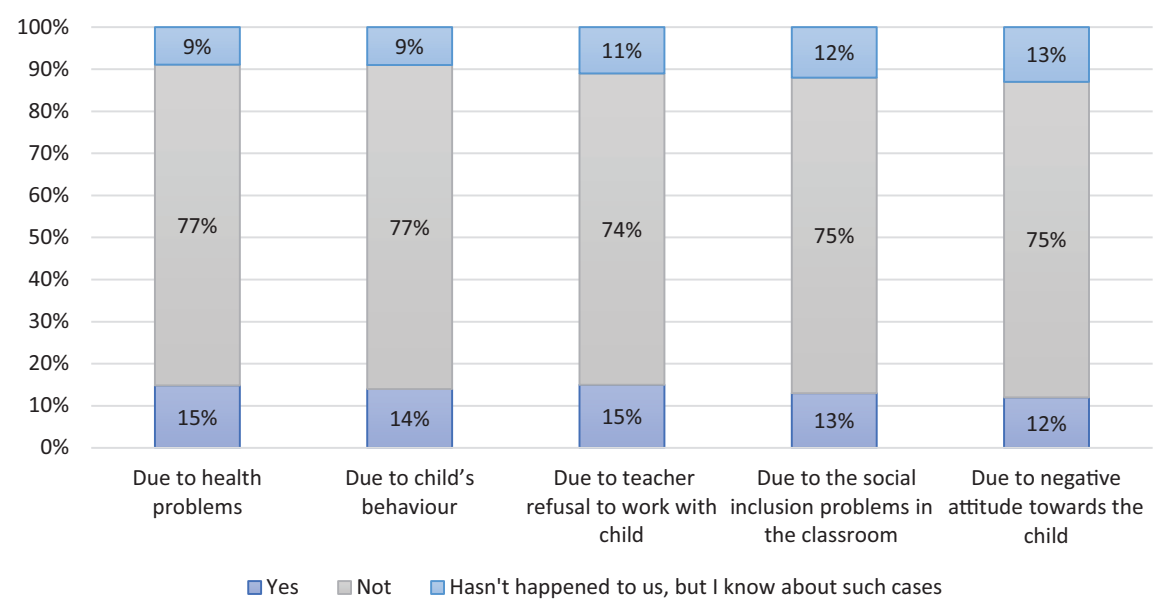

Figure 3. Refusal of access to interest-related education (\%) 
Researchers were interested in whether refusal was related to the child's disability. As illustrated in Figures 4, 5, 6, and 7, that parents whose children have a disability experience a refusal more often than those who do not have children with a disability.

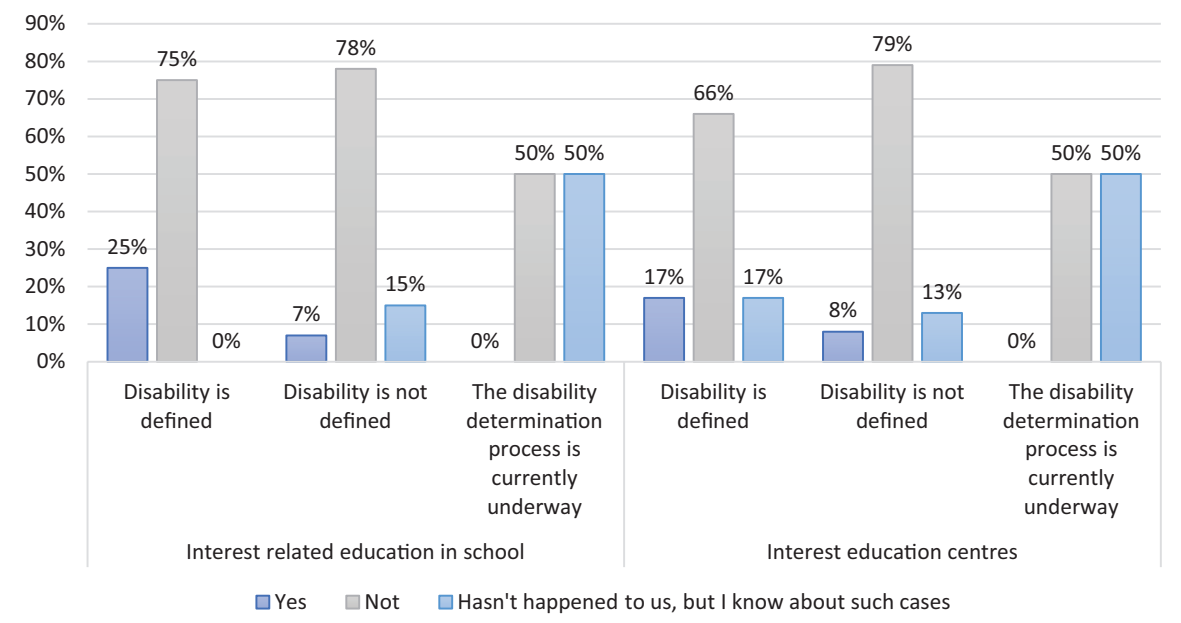

Figure 4. Refusal due to child's behaviour (\%)

Parents who have children with disabilities admit that in interestrelated education in school they have experienced refusal more often due to the child's behaviour and a teacher's refusal to work with the child than in interest education centres (see Figure 4, 5).

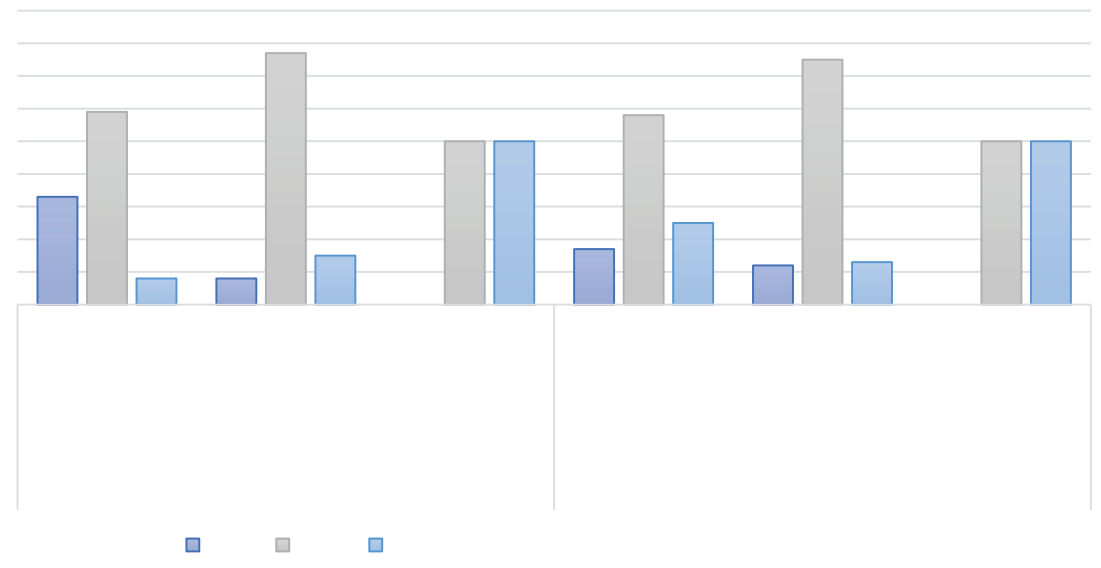

Figure 5. Refusal due to teacher's refusal to work (\%) 
Parents who have children with disabilities state that the refusal due to social inclusion problems in the classroom are more often experienced in interest-related education in school than in interest education centres. However, in both cases, more than a third in interest education centres and almost half of parents in interest education centres who had children with a disability admit that they were refused due to social inclusion problems (see Figure 6).

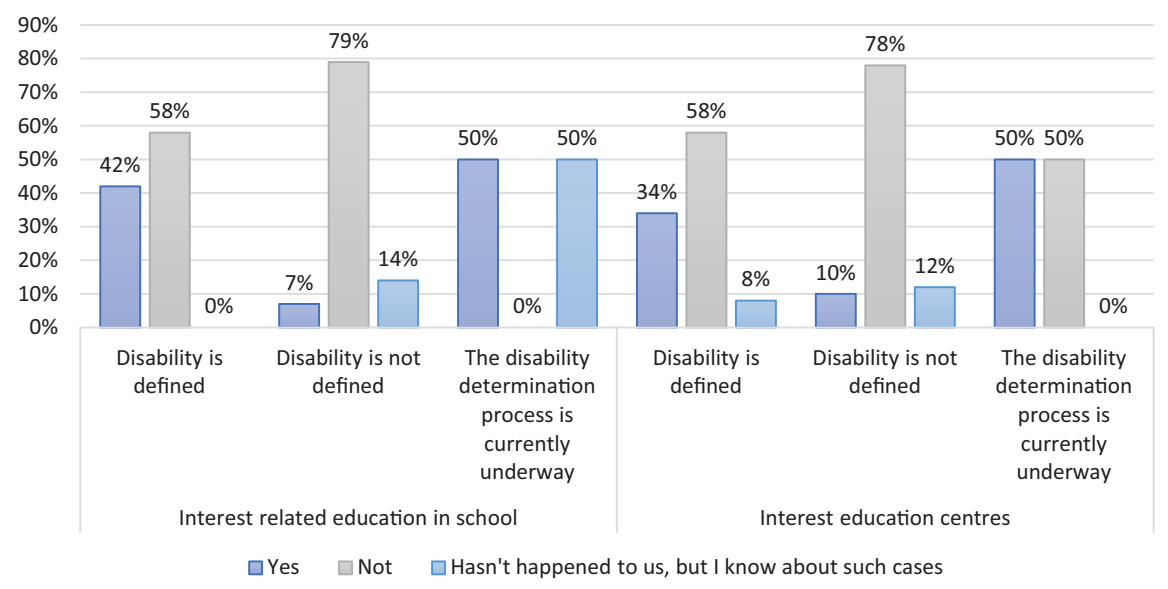

Figure 6. Refusal due to social inclusion problems in the classroom (\%)

Parents who have children with disabilities state that in interestrelated education in school they have experienced refusal more often due a teacher's negative attitude towards the child than in interest education centres (see Figure 7).

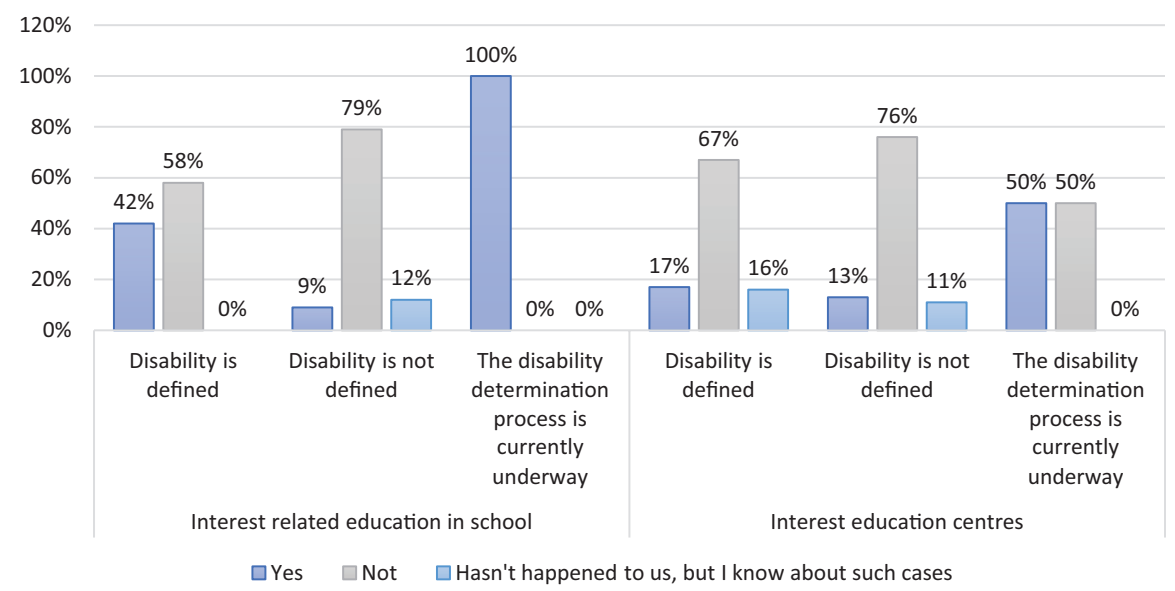

Figure 7. Refusal due to negative attitude towards the child (\%) 
Qualitatively summarized respondents' statements were divided into thematic groups outlining barriers to accessing an interest education and suggestions to overcome them.

First, they defined barriers to access. Parents acknowledge that there are several barriers to access. One of the most important barriers to access is that the offer of interest-related programmes differs between large and small cities. When living in the countryside, there is less availability and fewer choices in interest-related programmes.

"In a small town the choice is not as great as I would like. Looking at the offer in Riga, there is "envy" about the possibility of having so many interesting things for the child there.»

"In rural schools the offer is critical, there are no "interesting" specialists.»

Although the majority of programmes are offered in afternoons, the interest-related education programmes are generally still offered during parents' working hours.

"The desired changes could be related to the time - at what time the interest education groups are available».

Parents stated that the offer of interest education does not meet the demands of modern society and the interests of children.

«There is a feeling that the programme is from the Soviet era. They could introduce classes on healthy eating or lifestyle lessons.»

In many statements, parents stated that there are limited interest-related education offers for children with disabilities or for small children.

«For children with developmental disorders, there is a very small choice of classes.»

«For young children up to the age of 3, there are very few classes offered at municipal/Riga interest education centres. These centres are half empty in the first half of the day, so there could be an opportunity to use them.»

Unfortunately, the parents believe that pedagogues are not prepared to work with children with disabilities in interest-related education.

«Works only with children without disabilities.»

"There is a lack of staff and a lack of knowledge in how to communicate with such a child and how to include them in the group.»

«After the third class, the teacher asked me to choose another group because she could not deal with the discipline (with other children laughing at the special childss behaviour in a non-standard situation).» 
There are problems with children having a lack of understanding towards a child that is different.

«Do not want to dance or perform, because it should be explained to others that it is not a punishment to learn with a child with FT (functional disorder).»

Second, they made suggestions to overcome the barriers. Parents suggest that the only solution to overcome barriers to accessing interest-related education is the teachers' education. There is also evidence that parent's must rely on the next generation of teachers.

«Teachers should also be encouraged to work and involve healthy children in common lessons. It is difficult to be productive if teachers do not have the competence. These children scare them.»

«The new generation of educators is more open, accepting and understanding. They perceive everything more easily, do not complicate, and co-operation is mutually stimulating.»

\section{Discussions and conclusions}

Recognizing the limitations of this small-scale study, the survey sample suggests that whilst policy in Latvia promotes equality for all the children involved, there are some barriers to accessing interest-related education. From the parents' perspective, there is a lack of information about interestrelated education, children are too busy (overload can occur) to participate in interest -related education, there are no interest-related classes provided or conducted in some cases and there is no support staff during the classes that could assist in interest-related education. The findings correspond with theoretical conclusions, namely that there are barriers to access connected with accessibility of information (European Agency for Special Needs and Inclusive Education, 2015), access to the programme (Beddow, 2012), and availability of support (Cobb, 2015; Ramberg, 2013; Rose, Shevlin, Twomey, \& Zhao, 2017). A new aspect has also been discussed - child overload, which can be related to the personal characteristics of the child/ young person.

Although the majority of parents have had a positive experience concerning their children's access to interest-related education, almost a fifth of parents have had negative experiences or they knew somebody who was refused access to an interest education due to child/youth behaviour, social inclusion problems in the classroom and a teacher's negative attitude or a teacher's refusal to work with the child. Research reveals refusal is experienced more often by parents whose children have a disability. One can 
conclude that from the parents' perspective, children with disabilities have fewer equal opportunities to attend interest-related education programmes; therefore, access to the interest education service is not provided equally to all target groups of learners.

There are several barriers to accessing interest-related education programmes. Similar to previous studies, this study found barriers to accessing interest-related education in connection to the geographical aspect and proximity to the municipal centre (Kalnina et al., 2012; Nīmante et al., 2018). However, there were some additional barriers: the available interest-related education is "outdated"; inconvenient time for interest-related classes (i.e., interest education classes are at the same time as parents' working hours); insufficient supply (both quantity and variety) for young children and children/young people with disabilities; insufficient readiness of teachers to work with children/young people with disabilities; the inability to explain to other children/young people how to participate in the classes with children and young people with disabilities; and the negative attitude of other children towards children/young people with disabilities. The solution to overcome those barriers is teacher education.

As this was a small-scale study, future studies would probably benefit from exploring research questions in a wider range.

\section{References}

Ackah-Jn, F. R., \& Danso, J. B. (2019). Examining the physical environment of Ghanaian inclusive schools: How accessible, suitable and appropriate is such environment for inclusive education? International Journal of Inclusive Education, 23(2), 188-208.

Beddow, P. A. (2012). Accessibility theory for enhancing the validity of test results for students with special needs. International Journal of Disability, Development and Education: Inclusive Assessment and Accountability: Policy to Evidence-based Practices, 59 (1), 97-111.

Cobb, C. (2015). Is French immersion a special education loophole? ... And does it intensify issues of accessibility and exclusion? International Journal of Bilingual Education and Bilingualism, 18(2), 170-187.

European Agency for Special Needs and Inclusive Education. (2016). Early school leaving and learners with disabilities and/or special education needs: A review of research evidence focusing on Europe. Retrieved from https://www.european-agency. org/sites/default/files/Early\%20School\%20Leaving\%20Literature\%20Review.pdf

European Agency for Special Needs and Inclusive Education. (2017). Early school leaving and learners with disabilities and/or special educational needs: To what extent is research reflected in European Union policies? Retrieved from https://www. european-agency.org/sites/default/files/ESL\%20-\%20To\%20what $\% 20$ extent $\% 20$ is $\% 20$ research\%20reflected\%20in\%20EU\%20policies.pdf

Education Law (1998). Saeima: Riga. Retrieved from https://likumi.lv/ta/en/en/ id/50759

European Agency for Special Needs and Inclusive Education. (2015). Guidelines for accessible information: ICT for information accessibility in learning. Retrieved from https:// 
www.european-agency.org/sites/default/files/Guidelines $\% 20$ for $\% 20$ Accessible $\%$ 20Information_EN.pdf

Invaliditātes likums [Law of Disability] (2010). Saeima: Rīga. Retrieved from https://m. likumi.lv/doc.php?id = 211494

Kalniņa, D., Lepere, D., Vilcina, M., Maskal,onoka, I., Auziņa, I., Zemture, Dz., Caune, A., Matuseviča, Dz., Jansone, A., Tubina, V., Kḷaviņa, G., \& Svareniece, B. (2012). Interešu izglītība Latvijā un interešu izglîtības iestāžu loma [Interest-related Education in Latvia and the Role of Interest-related Educational Institutions]. Rìga. Retrieved from http:// www.cbjc.lv/petijumi/petijuma_zinojums_interesu_izglitiba_12.pdf

National Centre for Education, (n.n.). Interest-related Education. Retrieved from https:// visc.gov.lv/en/hobby/

Nīmante, D., Gehtmane-Hofmane, I., \& Vasečko, L̦. (2018). Bērna vajadzībās pamatotu pakalpojumu izstrāde ārpusǵimenes aprūpē esošu bērnu atbalsta nodrošināšanai [Development of children's needs based services for the provision of support for children living out of family care]. Efektīvas sadarbības projekts. Ziņojums. LU: Rīga. Retrieved from file:///C:/Users/User/Downloads/LU_petij._febr.2019\%20(1).pdf

Pavlovs, M. (2018). Opportunities of the development of values in the interest-related education of adolescents. In Society. Integration. Education. Proceedings of the International Scientific Conference (pp. 364-375) Volume II.

Ramberg, J. (2013). Special educational resources in the Swedish upper secondary schools: A total population survey. European Journal of Special Needs Education, 28(4), $440-462$.

Rose, R., Shevlin, M., Twomey, M., \& Zhao Y. (2017). Gaining access to support for children with special educational needs in the early years in Ireland: Parental perspectives. International Journal of Early Years Education, 25(4), 379-392.

United Nations Convention on the Rights of Persons with Disabilities (2006). United nation. Retrieved from https://www.un.org/development/desa/disabilities/conventionon-the-rights-of-persons-with-disabilities.html

This work was developed in framework of project "MyHUB - a onestop-shop on inclusion practices, tools, resources and methods for the pedagogical staff at formal and non-formal educational institutions", Project No 604454-EPP-1-2018-1-LV-EPPKA3-IPI-SOC-IN 